\title{
The Spatial Planning of Sustainable Transportation: Study Case of Semarang City
}

\author{
Dyah Maya Nihayah, Yunilia Nurfitrokha \\ Economics Faculty, Semarang State University \\ Corresponding Author: dyah_maya@mail.unnes.ac.id.
}

Recieved: January 2019 | Revised: March 2019, April 2019 | Accepted: June 2019

\begin{abstract}
As capital of Central Java, Semarang City has high accessibility since it has harbor, airport, and as the main lane of the mobility. The common urban issues felt by the community are traffic, air pollution, and the lack of public facilities for the non-motorize such as pedestrian track. It is necessary for urban managers and planners to conduct necessary planning and analysis for the development of urban transportation system through a strategic perspective. The objective of this article is to determine the process of spatial planning prioritized to achieve a sustainable transportation in Semarang City. This research was qualitative descriptive. Data were analyzed using the Analysis Hierarchy Process Method. Result showed that the planning of sustainable spatial transportation in Semarang City was arranged by some criteria in its planning; economic aspect, environment and the third is social aspect. The planning of sustainable transportation can be done by providing mode of reliable and well integrated mass transportation, the determining of policy of one RTH for one sub-district and providing a City Walk (a free vehicle area) so that the a friendly non-motorize city concept could be created.
\end{abstract}

Keywords: planning, sustainable, transportation

JEL classification: R11, R41, R42

How to Cite: Nihayah, D., \& Nurfitrokha, Y. (2019). The Spatial Planning of Sustainable Transportation: Study Case of Semarang City. Jurnal Ekonomi Pembangunan: Kajian Masalah Ekonomi dan Pembangunan, 20(2). 153-162. doi:https://doi.org/10.23917/jep.v20i2.7511

DOI: https://doi.org/10.23917/jep.v20i2.7511

\section{Introduction}

Currently, sustainable development issue has become an important issue that needs to be socialized to the community. Sustainable development is an effort of human beings to improve the quality of life by keep trying not to overlap the ecosystem that supported their lives. There are many empirical evidences showing that in many cities, plannings and public policies that are directed to realize sustainable developmentand feasibility of the city. Mentioning (Newman, 1999), (Yigitcanlar \& Dur, 2010), (Zavrl \& Zeren, 2010). One of the parts of the sustainable development is transportation. Urban transportation constitutes the main spatial structure of cities and has fundamental influences on shaping and orientation of urban development (Hatefi , 2018). Sustainable transportation means an effort to fulfill the need of transportation mobility of the current generation without degrading the ability of the future generation in fulfilling the need of transportation of its people with the environment friendly technology. This concept is interpreted as an effort in improving the facility for bike users, pedestrians, communication facilities, or the providing of cheap and environment friendly public transportation. In other words, the economy aspects, and social economy are inseparable unit to realize sustainable city layout (Puppim de Oliveira, 2013). 
(Litman, 2018) states that Sustainable transport planning recognizes that transport decisions affect people in many ways, so a variety objectives and impacts should be considered in the planning process. However, the most important thing is not only the outcome but process focused.

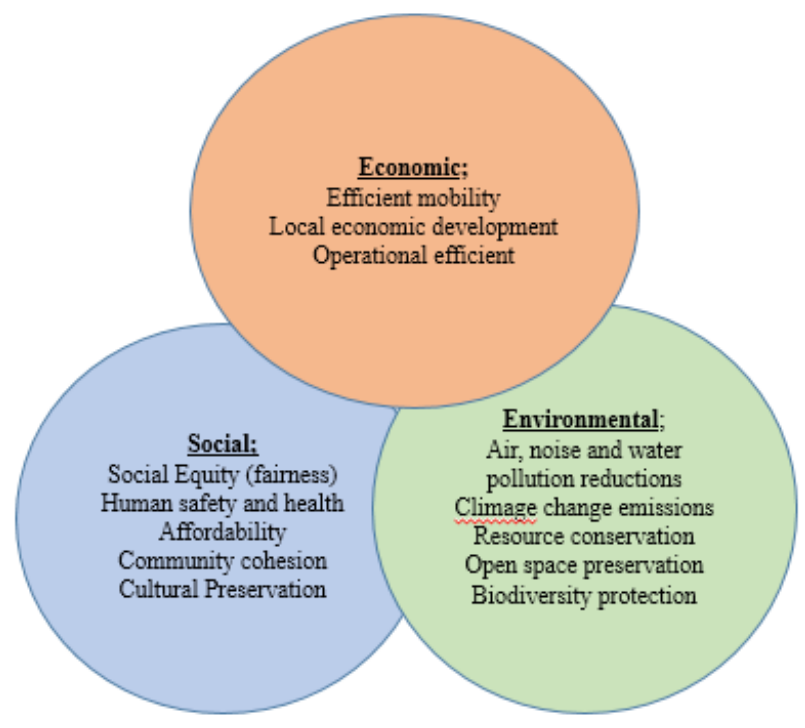

Source: (Litman, 2018)

Figure 1. Sustainable Transport Goals

This research conducted in Semarang City, because as capital of Central Java, Semarang
City has high accessibility since it has harbor, airport, and as the main lane of the mobility, so that indirectly, the city is the center of many kinds of urban activities which enable many urban problems to occur generally. The common urban issues felt by the community are traffic, air pollution, and the lack of public facilities for the non-motorize such as pedestrian track.

Traffic issue occurs because of the increasing number of the private vehicle ownership, the increasing number of road user and the absence of the improvement on the road service along with the growing number of population and the need of the people's mobility. The issue, of course will cause some bad effects such as the interruption of the goods delivery, time efficiency for workers, increasing number of accidents, fuel wasting, air pollution, etc. In a long term, this condition will cause problem complexity if it couldn't be overcome immediately, such as the degradation of life quality of the people, inefficiency, and the externality of the existing resources. Inefficiency mostly occurs in cities where the city scale increases (Piña \& Martínez, 2016). Sustainable development needs a balance among resources, environment, economy and social. The following is the data of the Number of Vehicles in Semarang City in 2014 - 2016.

Table 1. The Number of Public Transportation and Private Vehicle in Semarang City $2014-2016$

\begin{tabular}{|c|c|c|c|c|}
\hline \multirow{2}{*}{ No } & \multirow{2}{*}{ Private Vehicle } & \multicolumn{3}{|c|}{ Year } \\
\hline & & 2014 & 2015 & 2016 \\
\hline 1. & Sedan (car) & 102.602 & 108.758 & 141.385 \\
\hline 2. & Motorcycle & 647.292 & 686.130 & 1.179 .849 \\
\hline 3. & Pick up & 18.468 & 19.576 & 22.512 \\
\hline 4. & Truckwith 2 axis 4 tires & 10.260 & 10.875 & 12.506 \\
\hline 5. & Truckwith 2 axis 4 tires & 8.208 & 8.700 & 10.005 \\
\hline 6. & Truckwith 3 axis & 6.156 & 6.525 & 7.503 \\
\hline 7. & Truckwith 3 axis & 4.655 & 4.934 & 5.674 \\
\hline \multirow[t]{2}{*}{8.} & Trailer & 4.104 & 4.350 & 5.002 \\
\hline & $\begin{array}{c}\text { Total } \\
\end{array}$ & 801.745 & 849.848 & 1.384 .436 \\
\hline No & Public Transportation & 2014 & 2015 & 2016 \\
\hline 1. & $\mathrm{BRT}$ & 92 & 92 & 120 \\
\hline 2. & Angkot & 20.520 & 21.751 & 25.013 \\
\hline 3. & Small Bus (1-300 dll) & 13.864 & 14.695 & 16.899 \\
\hline \multirow[t]{2}{*}{4.} & Bus & 14.364 & 15.225 & 17.508 \\
\hline & Total & 48.840 & 51.763 & 59.474 \\
\hline
\end{tabular}


Besides the issue of traffic jam, other traffic issues is air (pollution) which mostly is caused by the exhaust from the vehicles. Result of the ambience of air quality measurement on the streets of Semarang City, it shows that the level of dust has gone beyond the air quality standard of $230 \mu \mathrm{gr} / \mathrm{m} 3$. Other than that, the level of carbon monoxides (CO) in Semarang City, even though it was still below the determined standard of $15000 \mu \mathrm{gr} / \mathrm{m} 3$, yet some spots has the highest CO polluted air in Kalibanteng Round about with the pollution level of $6629 \mu \mathrm{gr} / \mathrm{m} 3$. In the long term, such condition could cause inefficiency along with the increasing scale of the city $\mathrm{Hu}$ (2015), Piña \& Martínez (2016), Shathy \& Reza (2016).

Conservation of the city needs to be implemented as the form of environmentfriendly city development. This statement was delivered by Girard (2013). The form of conservation city in Semarang was with the number of Ruang Terbuka Hijau (RTH) (Green Open Space), where the number is still as much as $29 \%$ of the width of Semarang City or as much as 20,084.03 Ha. Such number is still insufficient to meet the minimum requirement for RTH of which should be $30 \%$ of the width of the city. In consequence, air pollution caused by the motorized vehicle couldn't be optimally decreased for the lack of capacity of RTH to absorb the CO. Other issues in Semarang City is the lack of Indonesian National Standardized and disable friendly pedestrian tracks. Pedestrian tracks that have met the SNI standard are located in A. Yani Road, Imam Bonjol Road, Pahlawan Road, Pemuda Road and Pandanaran Road. Therefore, it is necessary for urban managers and planners to conduct necessary planning and analysis for the development of urban transportation system through a strategic perspective. Most views on sustainable transportation emphasis on the elements of sustainability in transportation, or what constitutes a sustainable transportation system, rather than on the development process of getting one (Zuidgeest, Witbreuk , $\&$ Maarseveen , 2000). So, the objective of this article is to determine the process of spatial planning prioritized to achieve a sustainable transportation in Semarang City.

\section{Research Method}

\subsection{Type and Design of the Research}

The type of this research was qualitative descriptive. The data used in this research are primary and secondary data. Primary data was obtained from the key person who were the expert and master the condition of transportation in Semarang City very well. Secondary data was the data obtained from the second source, generally it was the data published by official institutions, so that the data was ready to use and in this research the data was obtained from Regional planning agency (Bappeda), Department of Transportation, Semarang Municipality, Board of Environment, etc or other related institution, also from the previous studies which of course related to the topic and the theme of this research.

\subsection{Method of Data Analysis}

This research used the method of Analysis Hierarchy Process (AHP) which was frequently used to assess the action related to the comparison of the importance between factor and some other alternatives. The method of AHP included consideration and personal values logically depended on the imagination, experience, and knowledge. This method could be used to recognize the type of program that needs to be prioritized in order to overcome the issue of transportation in Semarang City. In AHP analysis, to determine the prioritized elements in making decision was by making pairwise comparison using comparison matrix with scale. 
Avalaible online at http://journals.ums.ac.id, Permalink/DOI: 10.23917/jep.v20i2.7511

Jurnal Ekonomi Pembangunan: Kajian Masalah Ekonomi dan Pembangunan, 20 (2), 2019, 153-162

Table 2. Saaty's pairwise comparison scale

\begin{tabular}{lc}
\hline \multicolumn{1}{c}{ Verbal judgment } & Numeric value \\
\hline \multirow{2}{*}{ Extremely important } & 9 \\
Very Strongly more important & 8 \\
& 7 \\
Strongly more important & 6 \\
Moderately more important & 5 \\
Equally important & 4 \\
\hline
\end{tabular}

Source: Saaty (2008)

\subsection{Research Variables}

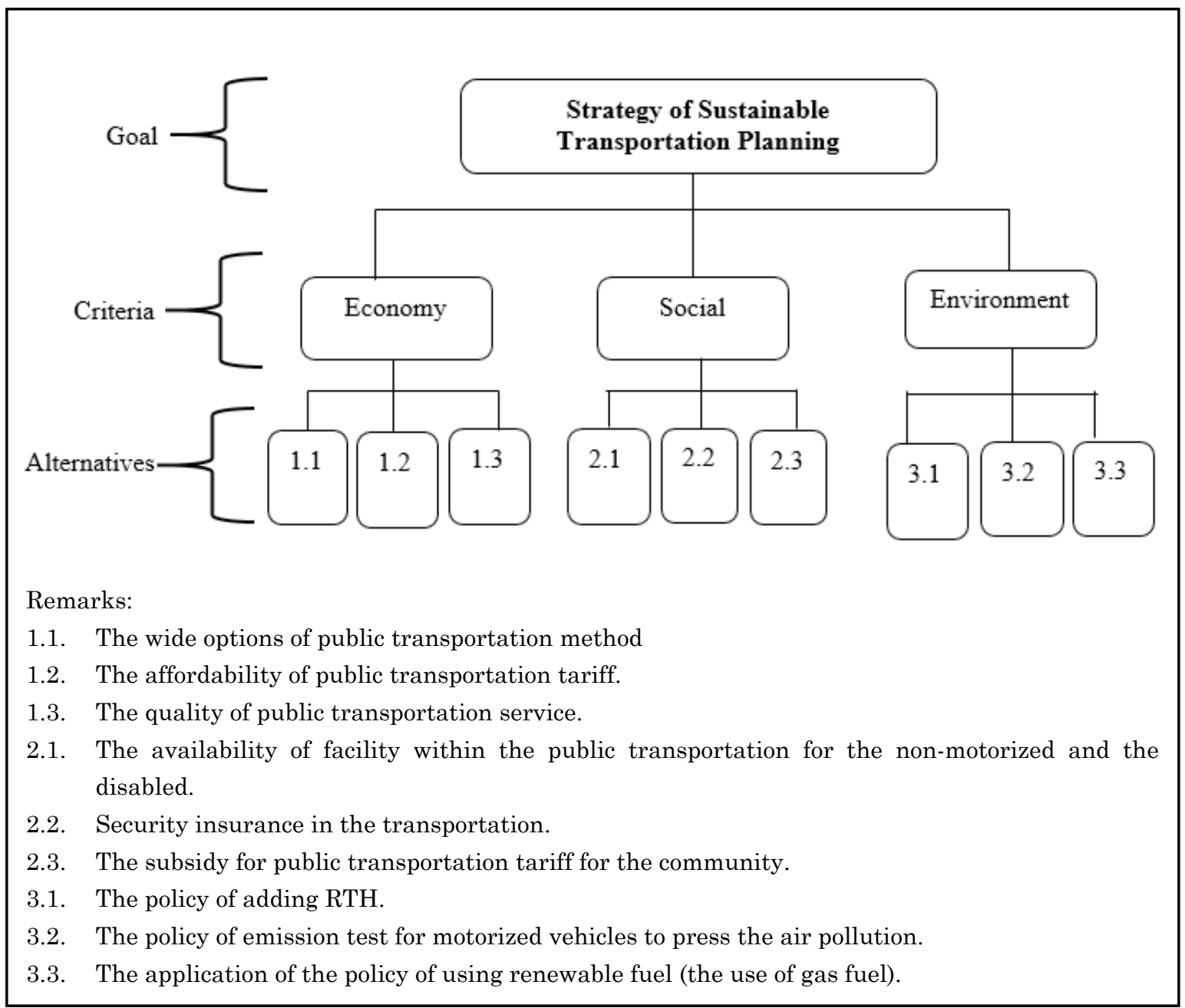

Figure 2. Decision hierarchy for Sustainable transportation spatial planning 
The variables used in this research was based on the indicators of sustainable transportation such as Economy, Social and Environment. Economy Indicator used variables: wide options of public transportation, public transportation affordability, service quality of public transportation. Social Indicator used variable of the accessibility of the facility in public transportation for the non-motorize and disabled, security insurancein the transportation, subsidized tariff of public transportation for the community. The last indicator was Environment. The variable used in this indicator was The Policy to add RTH, Policy of emission test for motorized vehicles to press the air pollution level, the application of the policy to use renewable fuel.

Sustainable transportation spatial planning in Semarang City was formulated using AHP method (Analysis Hierarchy Process). The alternative objectives and criteria used in AHP were formulated from result of interview, Indicators of sustainable transportation, as well as from the previous results of the related research. Figure 1, presented the frame of hierarchy process in making decision in sustainable spatial transportation in Semarang City.

The priority of strategic planning of sustainable transportation in Semarang City was implemented by choosing criteria that had been determined such as aspect of economy, social and environment. Afterward, from each aspect that became the criteria also had alternative of developing steps for each criteria that also chosen from the most prioritized.

\section{Results and Discussion}

\subsection{Results}

The initial stage implemented was by comparing the criteria: economy, social and environment so that result of which became the priority in sustainable transportation planning in Semarang City was obtained (Table 3)

The first priority was economy aspect with the weight value of 0.432 , the second priority was environment aspect with the weight value of 0.323 and the last priority was social aspect with the weight value of $0 / 238$. Inconsistency ratio value was $0.09<0.10$ (maximum limit) that means the analysis result was acceptable. Economic aspects is the most important aspect in sustainable transportation planning. It is due to Semarang City, as the capital of central java, is the center of government, trade and services that has positive affect for economic conditions and can influence other sectors in the surrounding area. The Government always strives to provide transportation that can guarantee the fulfillment of transportation through imposing reasonable costs for the community to realize justice in the transportation system. For example by increasing the number of corridors with affordable tariffs on public transportation, Bus Rapid Transit (BRT). Hopefully people will switch from private vehicles to public transportation.

The second priority is the environmental aspect with a weight value of 0.323 . Economic development always have a negative impact on the environment. Therefore a development plan is needed that incorporates environmental aspects to minimize the negative externalities of the transportation activities. The city government has tried to implement it by installing air pollution monitoring stations and making the target of reducing vehicle emission loads by at least $50 \%$ by 2020 . Other efforts made are by structuring the prevailing public transport system based on the road hierarchy and improving services and encouraging the use of vehicles motorized vehicles for short 1-3 km trips by providing construction of walking networks and green networks are important to reduce transportation costs.

Table 3.Criteria of Sustainable Transportation Spatial Planning in Semarang City

\begin{tabular}{clll}
\hline No & \multicolumn{1}{c}{ Aspect } & Weight & \multicolumn{1}{c}{ Remarks } \\
\hline 1 & Economy Aspect & 0.432 & Inconsistency Ratio $=$ \\
2 & Environment Aspect & 0.323 & 0.09 \\
3 & Social Aspect & 0.238 & \\
\hline
\end{tabular}

Source: Result of Primary Data Processing (2017)

Jurnal Ekonomi Pembangunan, ISSN 1411-6081, E-ISSN 2460-9331 
Table 4. Criteria of Economy Aspect

\begin{tabular}{clcc}
\hline No & Criteria of Economy Aspect & Weight Value & Remarks \\
\hline 1 & $\begin{array}{l}\text { The Wide Options of Public } \\
\text { Transportation Mode }\end{array}$ & 0.379 & Inconsistency Ratio $=$ \\
2 & $\begin{array}{l}\text { The affordability tariff of Public } \\
\text { Transportation }\end{array}$ & 0.331 & \\
3 & $\begin{array}{l}\text { Service quality of public } \\
\text { transportation }\end{array}$ & 0.289 & \\
\hline
\end{tabular}

Source: Result of Primary Data Processing (2017)

The third priority is the social aspect with a weight value of 0.238 . The social aspect tries to seek equality between communities vertically and horizontally in transportation services such as security and safety in transportation, provision of facilities for non-motorized users (bicycle trails) and persons with disabilities. For example, safety issues. Most people are not aware of that, even though the city government has tried to remind the strikers with the words "prohibited from removing limbs" that are affixed to public transportation.

The next stage was by comparing the alternatives from each criteria. Based on result of AHP processing, result could be obtained in table 4

Based on table 4, it could be seen that there were many options of public transportation mode had become the most prioritized alternative in planning the sustainable transportation in Semarang City with the priority percentage of $37.9 \%$. Next, the second priority was the affordability of tariff of public transportation with the priority percentage of $3.31 \%$. The last priority was service quality of public transportation with the percentage of $28.9 \%$. Inconsistency ratio of $0.02<0.10$ (maximum limit) which meant that result analysis was acceptable.

The important implication of such matter was that with more options of public transportation mode as well as the existence of well integrated mass transportation mode, it was expected that the community would use mass transportation more than private transportation so that the issue of transportation especially traffic jam could be decreased. The policy of providing public transportation modes in Semarang City was done through the development of mass public transportation (SAUM) in road and railwaybased main street corridors. The plan of the development of public transportation system on the streets was directed to the development of the public transportation facility that passed the urban main streets.

The second priority in planning the sustainable transportation was the affordability of the transportation tariff, currently Semarang Municipality, each year had budgeted funds as much as 47 billion rupiah to subside BRT tariff, the objective of the subsidy giving was that everyone could use the public transportation with affordable price and the cost spent was less than to use private vehicle. The rate applied by BRT was quite affordable since it used the similar tariff regardless the distance whether it was long or short with the rate of IDR 3,500,- in general and IDR 1.000,- for students.

The third priority in planning the sustainable transportation in Semarang City was the service quality of the public transportation. Service quality meant any activities done by the company in order to fulfill the hope of the consumer. Service, in this term, meant the service delivered by the public transportation provider in the form of easiness, speed, relation, ability and hospitality shown through their attitude and characteristics in providing the service for consumers' satisfaction. By providing the qualified transportation either in service or the physical condition of the means of transportation were expected to have more people used mass transportation mode. 
Avalaible online at http://journals.ums.ac.id, Permalink/DOI: 10.23917/jep.v20i2.7511

Jurnal Ekonomi Pembangunan: Kajian Masalah Ekonomi dan Pembangunan, 20 (2), 2019, 153-162

Table 5.Criteria of Environment Aspect

\begin{tabular}{clcc}
\hline No & Aspect Criteria of Environment & Weight Value & Remarks \\
\hline 1 & RTH Policy & 0.590 & \\
2 & $\begin{array}{l}\text { The policy to use renewable Fuel } \\
\text { (Gas Fuel/LNG) }\end{array}$ & 0.329 & $\begin{array}{l}\text { Inconsistency Ratio }= \\
0.01\end{array}$ \\
& $\begin{array}{l}\text { The policy of Emission Test for } \\
\text { Motorized vehicle. }\end{array}$ & 0.081 & \\
\hline
\end{tabular}

Source: Result of Primary Data Processing (2017)

Table 6.Criteria of Social Aspect

\begin{tabular}{clll}
\hline No & \multicolumn{1}{c}{$\begin{array}{c}\text { Criteria of Environment } \\
\text { Aspect }\end{array}$} & Weight & Remarks \\
\hline 1 & $\begin{array}{l}\text { The availability of public facility for } \\
\text { the non-motorized and disabled }\end{array}$ & 0.466 & \\
2 & $\begin{array}{l}\text { The security insurance in using } \\
\text { public transportation }\end{array}$ & $\begin{array}{l}\text { Inconsistency Ratio }= \\
0.02\end{array}$ \\
3 & $\begin{array}{l}\text { The subsidy of tariff of public } \\
\text { transportation for the community }\end{array}$ & \\
\hline
\end{tabular}

Source: Result of Primary Data Processing (2017)

Table 7. The Sequence of Alternative of Sustainable Spatial Transportation Planning in Semarang City from the Most Prioritized

\begin{tabular}{|c|c|c|c|}
\hline No & Criteria of Program & Weight & Remarks \\
\hline 1 & $\begin{array}{l}\text { The wide options of public } \\
\text { transportation modes }\end{array}$ & 0.196 & Aspect of Economy \\
\hline 2 & $\begin{array}{l}\text { The affordability of rate of public } \\
\text { transportation }\end{array}$ & 0.173 & Aspect of Economy \\
\hline 3 & $\begin{array}{l}\text { The service quality of public } \\
\text { transportation }\end{array}$ & 0.151 & Aspect of Economy \\
\hline 4 & The policy of adding the RTH & 0.146 & Aspect of Environment \\
\hline 5 & $\begin{array}{l}\text { The availability of public facilities for } \\
\text { the non-motorized and the disabled }\end{array}$ & 0.107 & Social Aspect \\
\hline 6 & $\begin{array}{l}\text { The insurance of security in using } \\
\text { public transportation }\end{array}$ & 0.092 & Social Aspect \\
\hline 7 & $\begin{array}{l}\text { The policy to use renewable fuel (gas } \\
\text { fuel) }\end{array}$ & 0.081 & Aspect of Environment \\
\hline 8 & $\begin{array}{l}\text { The subsidy of public transportation } \\
\text { rate for the community }\end{array}$ & 0.031 & Social Aspect \\
\hline 9 & $\begin{array}{l}\text { The policy of emission test for the } \\
\text { motorized vehicles }\end{array}$ & 0.020 & Aspect of Environment \\
\hline
\end{tabular}

Source: Result of Research Data Processing (2017)

Based on table 5 , it could be seen the policy of adding RTH was the alternative that became the priority in planning sustainable transportation in Semarang City with the percentage of priority of $59 \%$. The second priority was the policy to use renewable fuel (gas fuel) with the percentage of $32.9 \%$. The last priority was the policy for emission test for motorized vehicle with the percentage of $8.1 \%$. The inconsistency ratio was $0.01<0.10$ (minimum limit) which meant that the analysis result was acceptable.

Table 6 showed that the first priority in planning sustainable transportation in Semarang City was the availability of public facility for 
the non-motorized and the disabled with the percentage of $46.6 \%$ then the second priority was the security insurance in using public transportation with the percentage of $39.8 \%$ and the last alternative was the giving subsidy of public transportation rate for the community with the percentage of $13.6 \%$. Inconsistency ratio was $0.02<0.10$ (minimum limit) which meant that result of the analysis was acceptable. The important implication was that it needed to be leveled up.

The facility providing for the non-motorized and the disabled, because so far the only mass means of transportation that had provided facilities for disabled was BRT. Besides, the providing of facility for the non-motorize such as facility for pedestrians and the bicycle users needed to be leveled up more so that the people in Semarang City could use those facilities. Based on Table 7 it could be seen that the aspect chosen in the planning of sustainable transportation spatial in Semarang City without seeing the criteria and soon to be implemented was the wide options of public transportation modes with its priority percentage of $19.6 \%$.

The second priority was the affordability of public transportation rate with the percentage of $17.3 \%$ and the third was the service quality of public transportation with the priority percentage of $15.1 \%$ and the fourth priority was the policy of adding the RTH with the priority percentage of $14.6 \%$.

Table 7 shows that three criteria in the economic aspect are the first and foremost priorities in transportation planning, while the environmental aspects start in fourth and the social aspects appear in fifth. This result shows that the Semarang City Government still emphasizes the economic aspects of transportation policy. A few existing studies reported similar findings Abdallah, Wolf, \& Belloumi (2013), Tayarani, Poorfakhraei, Nadafianshahamabadi, \& Rowangould (2018) and Yang, Li, \& Cao (2015) suggest that urban economic activities require the role of transportation although it will bring negative externalities to social and environmental sustainability.

\subsection{Discussion}

The spatial policy of Semarang City's sustainable transportation has orientation towards providing transportation services that can guarantee the fulfillment of transportation costs through the imposition of appropriate costs for the community using transportation facilities and can realize justice in the transportation system. One of the efforts is to increase the number of Bus Rapid Transit (BRT) corridors. Rapid Transit Bus is one of the means of public transportation that provides services that are faster and more efficient compared to other public transportation equipment. The tariffs applied by BRT are quite affordable because they use the same tariff for long and close distance of IDR. 3,500, - for the public IDR. 1,000. This regulation will provide great benefits for the community because it will affect the decision making whether to use public transportation or private transportation.

The important implication of the issue was the wide options of public transportation modes as well as the well-integrated mass transportation mode was expected that the community would use more mass transportation than the private one so that the issue of transportation especially traffic jam could be decreased because the people had the preference and eventually they convert to use more public transportation and being nonmotorized. Such condition was relevant with research of Zavrl \& Zeren (2010) and Girard (2013), Puppim de Oliveira et al., (2013) and Currie, Truong, \& Gruyter (2018).

The second priority in planning sustainable transportation was the affordability of the transportation rate, through the subsidy of the transportation rate, the objective of such subsidy was that the community would choose to use mass transportation more than private transportation. The third priority in planning sustainable transportation in Semarang City was the service quality of the public transportation. With the 
availability of the good quality transportation in terms of its service and physically good condition of the means of the transportation, it was expected to have more people use mass transportation mode.

The fourth priority is the policy to add RTH as part of the environmental aspect. Actually, Sustainable transportation should be in line with environmental and social aspects. This is stated by Litman (2018) and Zuidgeest, Witbreuk , \& Maarseveen (2000). Nevertheless, the government continues to provide services and development of facilities and infrastructure optimally in both aspects. It was different with the application of green transportation in Surakarta City which chose to add more bicycle tracks since the number of RTH in Surakarta City had met the minimum standard of city RTH (Andriani \& Yuliastuti, 2013). The policy of Surakarta government in increasing the interest of the people to use bicycle was to keep the local wisdom and the existence of car free day program that aimed to reduce the emission level of carbon dioxide (CO2) in Surakarta City. The addition of RTH in Semarang City was done through a policy in issuing the Permit to Establish a Building (IMB) there was a set plan that ruled the provision of RTH, 20\% RTH public, and $10 \%$ RTH private. Besides the additional RTH done through the adding pedestrian tracks and the facilities for the non-motorized, where in the city pedestrian tracks there must be RTH. By adding RTH, it was expected that the air pollution caused by the vehicles could be reduced so that the city could be seen as an environment friendly city without reducing the mobility of its people in using transportation.

\section{Conclusions}

Sustainable spatial transportation planning in Semarang City to overcome the issue of pollution caused by the private vehicles was by the policy of adding the number of RTH through a set plan in the permit to establish a building implemented by the Department of City Layout and Housing of Semarang City as well as the application of the policy of one RTH one sub-district.
Sustainable spatial transportation planning in Semarang City to overcome the issue of the availability of pedestrian track (public facility for the non-motorized) was by adding the pedestrian tracks in Semarang City for the disabled such as the one in Imam Bonjol Road, besides, there will be provided a City Walk in the Old Town of Semarang so that the concept of the nonmotorized-friendly city could be created.

Thus, the sustainable spatial transportation planning in the urban area must be pressed on the provision of transportation with environmentfriendly technology, provision of reliable and integrated mass transportation modes through the improvement of the facilities for the nonmotorized (bicycle users, pedestrians). Besides, there need a collaboration between the private and the government in improving the RTH so that the minimum standard of RTH could be met and reduced the air pollution caused by the vehicles.

\section{Acknowledgement}

The authors would like to acknowledge Semarang State University for its assistance and supports.

\section{References}

Abdallah, K., Wolf, D., \& Belloumi, M. (2013). - Indicators for sustainable energy development: A multivariate cointegration and causality analysis from Tunisian road transport sector. Renewable and Sustainable Energy Reviews, 34-43.

Andriani, D. M., \& Yuliastuti , N. (2013). Penilaian Sistem Transportasi yang Mengarah pada Green Transportation di Kota Surakarta. Jurnal Pengembangan Wilayah dan Kota, 9(2), 183-193.

Currie, G., Truong, L., \& Gruyter, C. (2018). Regulatory structures and their impact on the sustainability performance of public transport in world cities. Research in Transportation Economics, 1-8.

Girard, L. F. (2013). Toward a Smart Sustainable Development of Port Cities/Areas: The 
Role of the "Historic Urban Landscape" Approach. Sustainability, 5, 4329-4348.

Hatefi , S. (2018). Strategic planning of urban transportation system based on sustainable development dimensions using an integrated SWOT and fuzzy COPRAS approach. Global. J. Environ. Sci. Manage, 4(1), 99-112.

$\mathrm{Hu}$, R. (2015). Sustainable Development Strategy for the Global City: A Case Study of Sydney. Sustainability, 7, 4549-4563.

Litman, T. A. (2018). Well Measured, Developing Indicators for Sustainable and Livable Transport Planning . Victoria Transport Policy Institute .

Newman, P. W. (1999). Sustainability and cities: extending the metabolism model. Landscape and Urban Planning, 44(4), 219-226.

Piña, W. H., \& Martínez, C. I. (2016). Development and Urban Sustainability: An Analysis of Efficiency Using Data Envelopment Analysis. Sustainability, 8(2), 148.

de Oliveira, J. A. P., Doll, C. N., Balaban, O., Jiang, P., Dreyfus, M., Suwa, A., ... \& Dirgahayani, P. (2013). Green economy and governance in cities: assessing good governance in key urban economic processes. Journal of Cleaner Production, 58, 138-152.

Saaty, T. L. (2008). Decision making with the analytic hierarchy process. Int. J. Services Sciences, 1(1), 83-98.

Shathy , S. T., \& Reza, M. I. (2016). Sustainable Cities: A Proposed Environmental Integrity Index (EII) for Decision Making. Frontiers in Environmental Science, 4(82).

Tayarani, M., Poorfakhraei, A., Nadafianshahamabadi, R., \& Rowangould, G. (2018). Can regional transportation and land-use planning achieve deep. Transportation Research Part D, 222-235.

Yang, W., Li, T., \& Cao, X. (2015). Examining the impacts of socio-economic factors, urban form and transportation development on $\mathrm{CO} 2$ emissions from transportation in China:. Habitat International, 212-220.

Yigitcanlar, T., \& Dur, F. (2010). Developing a Sustainability Assessment Model: The Sustainable Infrastructur, LandUse, Environment and Transport Model. Sutainability, 2(1), 321-340.

Zavrl, M. Š., \& Zeren, M. T. (2010). Sustainability of Urban Infrastructures. Sustainability, 2(9), 2950-2964.

Zuidgeest, M., Witbreuk , M., \& Maarseveen , M. v. (2000). Sustainable Transport: A Review From A Pragmatic Perspective. South Africa: Document Transformation Technologies. 